\title{
Struktur Komunitas Echinodermata pada Berbagai Tipe Habitat di Daerah Intertidal Pantai Lakeba, Kota Baubau Sulawesi Tenggara
}

\author{
WD. Syarni Tala*, Kusrini, Jumiati \\ Program Studi Pendidikan Biologi, FKIP, Universitas Muhammadiyah Buton \\ Jl. Betoambari No. 36 - Baubau, Sulawesi Tenggara 93712 Indonesia \\ email: talaws525@gmail.com
}

\section{Abstract \\ The Community Structure of Echinoderms in Various Habitat Types in Intertidal Area of Lakeba Beach, Baubau Town}

\begin{abstract}
Echinoderms are one of organisms that inhabit intertidal areas which have important ecological roles in marine ecosystems, also have high economic values. The community structure and distribution pattern of Echinoderms in the intertidal area can provide an overview of the condition of the Echinoderm community. This research aims to determine the community structure of Echinoderms in various habitat types in the intertidal areas of Lakeba Beach, Baubau Town. The community structure of Echinoderms were observed using quadratic transec method. Echinoderms found were 777 individuals consisting of 18 species from 5 classes. Echinoderms were distributed in four habitat types, i. e. sandy, sand covered with seagrass, rocky, and rock covered with algae habitats. The highest abundance of Echinoderm was Ophiocoma scolopendrina (Ophiuroidea) and the lowest were Maretia planulata, Arachnoides placenta (Echinoidea), Holothuria scabra, H. leucospilota, Stichopus horrens (Holothuroidea), and Isocrinidae (Crinoidea). The species diversity of Echinoderms was categorized as moderate $\left(H^{\prime}=1,42180\right)$, species evenness was moderate $(E=0,49191)$, and no dominant species of Echinoderm community $(D=0,36601)$. Echinoderm community living in the intertidal area was influenced by antropogenic factors.
\end{abstract}

Keywords: Community, Distribution, Echinoderms, Antropogenic

\begin{abstract}
Abstrak
Echinodermata merupakan salah satu organisme yang mendiami daerah intertidal yang memiliki peran ekologis penting bagi ekosistem laut, juga memiliki nilai ekonomis yang tinggi. Struktur komunitas dan pola distribusi Echinodermata pada daerah intertidal dapat memberikan gambaran mengenai kondisi komunitas Echinodermata. Penelitian ini bertujuan untuk mengetahui struktur komunitas dan pola distribusi Echinodermata di daerah intertidal Pantai Lakeba, Kota Baubau. Struktur komunitas dan pola distribusi Echinodermata diamati menggunakan metode transek kuadrat. Echinodermata yang ditemukan berjumlah 777 individu yang terdiri atas 18 jenis dari 5 kelas. Echinodermata terdistribusi pada empat tipe habitat yaitu habitat pasir, pasir yang ditutupi lamun, batu, dan batu yang ditutupi alga. Echinodermata yang memiliki kelimpahan tertinggi adalah Ophiocoma scolopendrina (Ophiuroidea) dan kelimpahan terendah adalah Maretia planulata, Arachnoides placenta (Echinoidea), Holothuria scabra, H. leucospilota, Stichopus horrens (Holothuroidea), dan Isocrinidae (Crinoidea). Keanekaragaman jenis Echinodermata dikategorikan sedang $\left(H^{\prime}=1,42180\right)$, kemerataan jenis sedang $(E=0,49191)$ dan tidak ada jenis yang dominan dalam komunitas Echinodermata $(D=0,36601)$. Komunitas Echinodermata yang hidup di daerah intertidal pantai dipengaruhi oleh faktor antropogenik.
\end{abstract}

Kata kunci: Komunitas, Distribusi, Echinodermata, Antropogenik 


\section{PENDAHULUAN}

Daerah intertidal merupakan daerah pasang surut yang memisahkan laut dari daratan. Daerah ini membentang dari batas surut terendah hingga batas pasang tertinggi (Meadows \& Campbell, 1988). Pada daerah intertidal, kondisi berbagai faktor lingkungan sangat berbeda dengan bagian laut lainnya. Daerah ini memiliki fluktuasi harian faktor lingkungan yang ekstrem, sehingga organisme yang hidup pada daerah ini memiliki kisaran toleransi yang bervariasi terhadap faktor lingkungan. Masing-masing organisme akan menempati habitat yang paling sesuai dengan kisaran toleransinya, akibatnya organisme yang hidup pada daerah intertidal sangat beragam jenisnya (Garrison \& Ellis, 2016). Organisme yang hidup pada daerah intertidal antara lain Arthropoda, Mollusca, Cnidaria, Annelida, Porifera, Brachiopoda, dan Echinodermata (Hwang et al., 2015).

Echinodermata merupakan hewan invertebrata yang memiliki duri atau tonjolon pada permukaan luar tubuhnya. Hewan ini memiliki sejumlah ciri khas yang tidak dimiliki filum lain yaitu memiliki endoskeleton dari kalsium karbonat, memiliki sistem pembuluh air, memiliki pediselaria berbentuk penjepit, memiliki papula yang berperan dalam respirasi, dan tubuh bersimetri pentaradial saat dewasa. Echinodermata terdiri atas 5 kelas yaitu Asteroidea (bintang laut), Echinoidea (duri babi), Ophiuroidea (bintang ular), Holothuroidea (timun laut), dan Crinoidea (lili laut)(Hickman et al., 2017; Miller \& Harley, 2013).

Echinodermata memiliki peran yang sangat penting baik secara ekologis maupun ekonomis. Secara ekologis, Echinodermata merupakan komponen penting dalam jaringjaring makanan di laut. Beberapa peran Echinodermata yaitu sebagai predator (Asteroidea), herbivor (Echinoidea), dan detritivor (Ophiuroidea, Holothuroidea, dan Crinoidea) (Hickman et al., 2017). Selain itu, Echinodermata juga dapat berperan sebagai bioindikator kualitas perairan terhadap polusi logam berat seperti kadmium, tembaga, timbal, seng, dan nikel (Coteur et al., 2003; Portocali et al., 1997). Secara ekonomis, beberapa kelas Echinodermata telah lama dibudidayakan masyarakat di berbagai belahan dunia termasuk Indonesia karena bernilai ekonomis tinggi. Kelas ini yaitu Echinoidea dan Holothuroidea. Organ yang dimanfaatkan dari Echinoidea adalah gonad atau lebih dikenal dengan istilah telur (roe), sedangkan Holothuroidea adalah dinding tubuhnya. Bagian tubuh yang dimanfaatkan ini sangat kaya dengan protein. Khusus untuk Holothuroidea, dinding tubuhnya tidak hanya dimanfaatkan sebagai bahan makanan kaya protein, namun juga sebagai obat tradisional hingga bahan baku kosmetik (Brown \& Eddy, 2015).

Echinodermata memiliki potensi yang sangat besar bagi masyarakat untuk dikembangkan. Namun apabila potensi ini dieksploitasi secara berlebihan, hal ini akan mengancam keberadaan Echinodermata. Langkah awal untuk meminimalkan eksploitasi Echinodermata adalah dengan mengetahui struktur komunitas Echinodermata. Pengetahuan mengenai struktur komunitas Echinodermata sangat penting karena dapat memberikan gambaran mengenai kondisi komunitas Echinodermata saat ini. Sejauh ini, sudah ada banyak penelitian yang mengkaji struktur komunitas Echinodermata di berbagai wilayah di Indonesia, namun penelitian yang secara spesifik mengkaji struktur komunitas Echinodermata pada berbagai tipe habitat tempat hidupnya belum banyak dilakukan. Oleh karena itu, penelitian ini menjadi sangat penting untuk dilakukan.

Kota Baubau merupakan salah satu daerah di Pulau Buton yang sebagian besar masyarakatnya tinggal di pesisir pantai (BPS, 2021). Keberadaan masyarakat yang tinggal di pesisir akan sangat mempengaruhi kehidupan organisme yang hidup pada daerah intertidal karena daerah intertidal langsung bersinggungan dengan wilayah pesisir. Akibatnya kehidupan organisme yang hidup di daerah intertidal menjadi terancam, khususnya Echinodermata. Penelitian mengenai struktur komunitas Echinodermata di daerah intertidal pantai Kota Baubau pernah dilaporkan sebelumnya (Samritin et al., 2019), namun hasil penelitian ini belum menggambarkan kondisi Echinodermata secara menyeluruh. Berdasarkan latar belakang tersebut, maka penulis melakukan penelitian mengenai Struktur Komunitas 
Echinodermata pada Berbagai Tipe Habitat di Daerah Intertidal Pantai Lakeba, Kota Baubau.

\section{MATERI DAN METODE}

Penelitian ini dilaksanakan pada bulan Januari - Maret 2021 di daerah intertidal Pantai Lakeba Kota Baubau Sulawesi Tenggara. Pantai Lakeba merupakan bagian dari Selat Buton. Pantai ini menghadap ke arah Barat Laut, berhadapan dengan Pulau Kadatua. Daerah intertidal pantai ini bersubstrat pasir, pasir yang ditutupi lamun, batu, dan batu yang ditutupi alga coklat dan alga hijau. Di bagian Barat Daya dan Timur Laut pantai, substrat didominasi oleh batu yang ditutupi alga di bagian intertidal atas dan pasir berlamun di bagian intertidal bawah. Di bagian tengah pantai substrat didominasi oleh pasir di bagian intertidal atas dan pasir berlamun di bagian intertidal bawah (Gambar 1).

Struktur komunitas Echinodermata diamati menggunakan metode transek kuadrat. Transek yang dipasang berjumlah 6 buah. Jarak antar transek adalah 50 - 60 meter. Peletakan transek secara purposive sampling, berdasarkan jenis Echinodermata yang dijumpai dan tipe substrat. Transek sepanjang $50 \mathrm{~m}$ ini dipasang tegak lurus garis pantai dan pada masing-masing transek ditempatkan 4 buah plot berukuran $5 \times 5 \mathrm{~m}$ secara berselang-seling dari transek dengan selisih antar plot adalah 10 meter.
Echinodermata yang ditemukan didokumentasikan bagian oral dan aboralnya di atas kertas grafik yang telah dilaminating, dicatat jenis, jumlah individu, dan tipe habitatnya (pasir, batu, lamun, dan/atau alga). Echinodermata ini diidentifikasi menggunakan buku identifikasi dan jurnal yang mendukung (Clark \& Rowe, 1971; Devaney, 1970, 1978; Massin et al., 2002; Purwati \& Lane, 2004; Samyn, 2003; Vandenspiegel et al., 1998). Echinodermata diklasifikasikan berdasarkan klasifikasi jenis pada WoRMS, World Register of Marine Species (http://www.marinespecies.org). Lamun dan alga yang terdapat pada plot penelitian juga diidentifikasi jenisnya: lamun (Azkab, 1999), alga (Jha et al., 2009).

Data yang diperoleh dianalisis untuk mengetahui kelimpahan (Odum \& Barett, 2005), keanekaragaman jenis menggunakan indeks keanekaragaman Shannon-Wiener $\left(H^{\prime}\right)$, kemerataan menggunakan indeks kemerataan jenis Pielou (E), dan dominansi menggunakan indeks dominansi Simpson (D). Kriteria indeks keragaman Shannon Wiener $\left(H^{\prime}\right)$ dikelompokkan menjadi tiga yaitu keanekaragaman tinggi $\left(H^{\prime}>3,22\right)$, keanekaragaman sedang $\left(1,00 \leq H^{\prime} \leq 3,22\right)$, dan keanekaragaman rendah $\left(H^{\prime}<1,00\right)$ (Odum \& Barett, 2005). Kriteria indeks kemerataan jenis Pielou dikelompokkan menjadi tiga yaitu tinggi $(E>0,6)$, sedang $(0,4$ $\leq E \leq 0,6)$, dan rendah $(E<0,4)$ (Krebs, 1989).

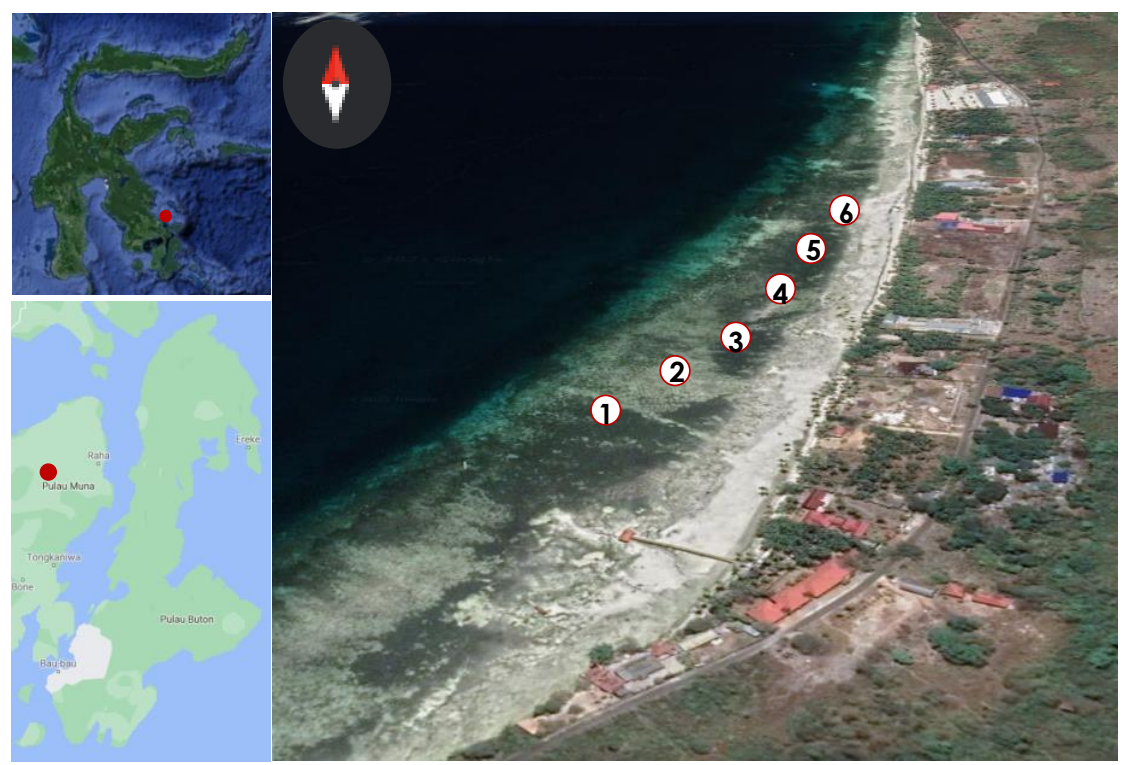

Gambar 1. Lokasi Penelitian di daerah intertidal Pantai Lakeba, Kota Baubau, Sulawesi Tenggara 
Kriteria indeks dominansi Simpson dibagi menjadi dua yaitu tidak ada spesies yang dominan $(0<D<0,5)$ dan ada spesies yang dominan $(0,5 \leq D \leq 1)$ (Odum \& Barett, 2005).

\section{HASIL DAN PEMBAHASAN}

Secara umum, komunitas Echinodermata di daerah intertidal Pantai Lakeba ditemukan pada empat tipe habitat yang berbeda yaitu pasir, pasir yang ditutupi lamun, batu, dan batu yang ditutupi alga. Empat tipe habitat ini dapat dilihat pada Gambar 2. Pada habitat pasir yang ditutupi lamun, ditemukan lima jenis lamun yaitu Thalassia hemprichii, Cymodocea rotundata, Enhalus acoroides, Haludole pinifolia, dan Halophila ovalis. Pada habitat batu yang ditutupi alga ditemukan enam jenis alga yaitu Valonia aegagropila, Ulva rigida, Sargassum cinctum, S. cinereum, Sargassum sp., dan Padina boergesenii. Jenis Echinodermata yang mendiami berbagai tipe habitat ini terdiri atas 18 jenis Echinodermata dari 5 kelas. Jenis Echinodermata paling banyak berasal dari Kelas Echinoidea sebanyak 8 jenis, diikuti oleh Holothuroidea sebanyak 5 jenis, Ophiuroidea sebanyak 3 jenis, dan paling sedikit adalah Asteroidea dan Crinoidea, masing-masing satu jenis (Tabel 1).

Jumlah jenis Echinodermata yang ditemukan di daerah intertidal Pantai Lakeba jauh lebih banyak dibandingkan jenis Echinodermata yang ditemukan di daerah intertidal Pantai Nirwana yang hanya 5 jenis (Samritin et al., 2019). Kedua pantai ini hanya berjarak $\pm 5 \mathrm{~km}$. Perbedaan jumlah jenis ini diduga karena adanya perbedaan tipe habitat Echinodermata. Pada daerah intertidal Pantai Nirwana, tipe habitat utama adalah pasir, sehingga jumlah jenis yang ditemukan lebih sedikit. Pada daerah intertidal Pantai Lakeba, tipe habitat lebih beragam, sehingga memungkinkan bagi berbagai jenis Echinodermata untuk menempati berbagai tipe mikrohabitat sesuai relung ekologisnya.

Jumlah jenis Echinodermata yang ditemukan di Pantai Lakeba ini sama dengan yang ditemukan di perairan Pulau WangiWangi dan Pulau Kapota, Wakatobi yaitu 18 jenis (Yusron, 2016). Namun dari jumlah ini, hanya 6 jenis yang sama dengan jenis yang ditemukan di Pantai Lakeba. Perbedaan ini mungkin disebabkan oleh kondisi geografis daerah intertidal perairan Pulau Wangi-Wangi dan Pulau Kapota yang cukup berbeda dengan Pantai Lakeba. Pada daerah intertidal perairan Pulau Wangi-Wangi dan Pulau Kapota, lamun dan alga yang tumbuh dan berkembang dengan baik. Kedua pulau ini juga dikelilingi oleh terumbu karang tepi (fringing reef). Hal ini diduga menjadi penyebab berbedanya organisme yang ditemukan.

Berdasarkan hasil pengamatan, dari 18 jenis Echinodermata yang ditemukan di daerah intertidal Pantai Lakeba, 5 jenis ditemukan pada habitat pasir, 9 jenis pada habitat pasir yang ditutupi lamun, 6 jenis pada habitat batu, dan 6 jenis pada habitat batu yang ditutupi alga (Gambar 3.a). Data ini menunjukkan bahwa habitat pasir yang ditutupi lamun paling banyak dihuni oleh Echinodermata. Sembilan jenis Echinodermata ini terdiri atas 4 jenis Echinoidea, 4 jenis Holothuroidea, dan satu jenis Asteroidea.

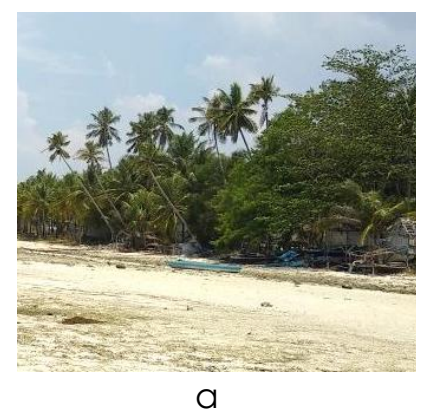

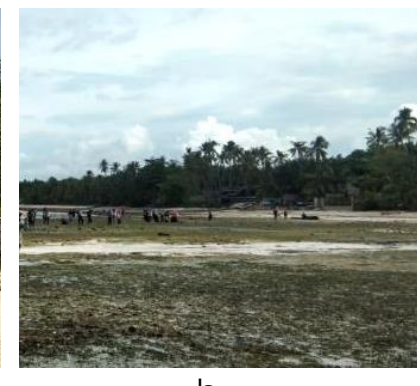

$\mathrm{b}$

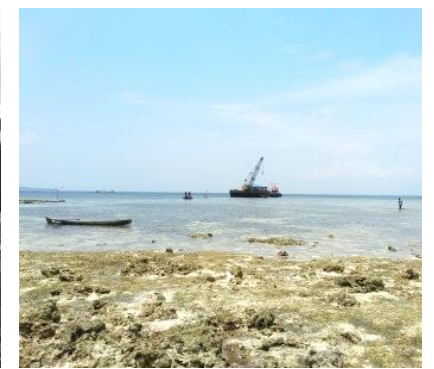

C

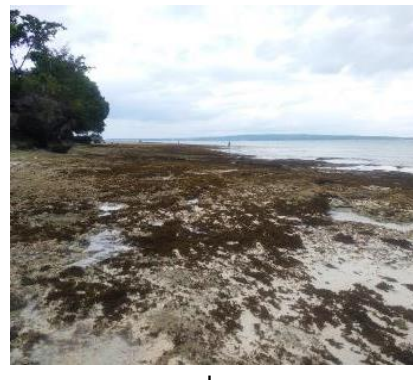

d

Gambar 2. Tipe habitat Echinodermata di daerah intertidal Pantai Lakeba: a. Pasir; b. Pasir yang ditutupi lamun; c. Batu; d. Batu yang ditutupi alga 
Banyaknya jenis Echinodermata yang ditemukan pada habitat pasir ditutupi lamun diduga karena habitat ini sangat ideal bagi Echinodermata untuk tumbuh dan berkembangbiak. Lamun menyediakan tempat berlindung bagi Echinodermata dari predator, juga dari terpaan sinar matahari saat air laut surut. Beberapa jenis bulu babi yang ditemukan di lokasi seperti Salmacis sphaeroides dan Tripneustes gratilla memanfaatkan daun-daun lamun untuk melindungi tubuhnya dari teriknya sinar matahari. Lamun juga menjadi sumber makanan bagi Echinodermata seperti bulu babi $T$. gratilla, utamanya lamun jenis $T$. hemprichii (Klumpp et al., 1993). Tidak hanya itu, lamun juga menyediakan sumber makanan bagi Echinodermata. Banyak mikroalga dan mikrofitobentos yang hidup menempel pada daun dan rizoma lamun. Mikroalga merupakan makanan bagi larva Echinodermata, sedangkan mikrofitobentos merupakan makanan utama bagi Echinodermata pemakan deposit seperti Holothuroidea. Lamun juga mampu memerangkap nutrien sehingga substrat pada dasar lamun sangat kaya bahan organik (Hartati et al., 2017). Banyaknya jenis Echinodermata pada habitat pasir yang ditutupi lamun senada dengan hasil penelitian Muzaki et al. (2019) yang menemukan 27 jenis Echinodermata di padang lamun Pantai Pacitan.

Echinodermata paling sedikit ditemukan pada habitat pasir yaitu sebanyak 5 jenis (Gambar 3.a). Kelima jenis ini yaitu Maretia planulata, Brissus latecarinatus, Arachnoides placenta, Holothuria atra, dan Isocrinidae. Lili laut Isocrinidae ini tidak dapat diidentifikasi hingga tingkat jenis karena lili laut ini sangat sensitif terhadap pergerakan air, sehingga saat mendeteksi adanya pergerakan air di sekitarnya, lili laut ini langsung menarik tubuhnya masuk ke dalam substrat. Hal ini menyebabkan lili laut ini hanya dapat didokumentasikan, sehingga identifikasinya hanya dapat dilakukan hingga tingkat famili. Namun keberadaan Isocrinidae pada daerah intertidal Pantai Lakeba cukup menarik. Beberapa penelitian Echinodermata yang telah dilakukan di daerah intertidal tidak ditemukan adanya Crinoidea (Ghafari et al., 2019; Muzaki et al., 2019; Suwartimah et al.,
2017; Vindia et al., 2018; Yusron, 2016). Menurut Yusron (2016), Crinoidea umumnya ditemukan di daerah tubir. Daerah tubir (reef slope atau fore reef) adalah daerah terjauh dari pantai yang terletak di bagian luar rataan terumbu dan berhadapan langsung dengan laut terbuka. Isocrinidae yang ditemukan ini mungkin terbawa arus hingga ke daerah intertidal Pantai Lakeba.

Jenis Echinodermata yang ditemukan pada berbagai tipe habitat di Pantai Lakeba memiliki jumlah individu yang beragam. Jumlah individu ini cukup berbanding terbalik dengan jumlah jenis yang ditemukan. Walaupun habitat pasir yang ditutupi lamun memiliki jumlah jenis terbanyak, namun habitat dengan jumlah individu terbanyak adalah habitat batu yang ditutupi alga karena jumlah total individu yang ditemukan pada habitat pasir yang ditutupi lamun hanya 219 individu, sedangkan pada habitat batu yang ditutupi alga sebanyak 425 individu (Gambar 3.b).

Perbedaan jumlah individu pada kedua tipe habitat ini banyak dipengaruhi oleh faktor antropogenik. Jenis yang paling banyak ditemukan pada habitat pasir berlamun adalah bulu babi S. sphaeroides. Bulu babi ini disebut juga kaombai oleh masyarakat setempat. Bulu babi ini merupakan jenis yang dikonsumsi masyarakat. Pada saat penelitian ini dilakukan, masyarakat yang tinggal di sekitar Pantai Lakeba juga beramai-ramai turun ke laut karena waktu ini bertepatan dengan surut terendahnya air laut. Mereka datang dengan tujuan untuk mengambil berbagai jenis hasil laut, utamanya bulu babi jenis S. sphaeroides. Mereka membawa ember yang diisi penuh dengan bulu babi tersebut. Akibatnya, sampling bulu babi ini tidak dapat dilakukan dengan maksimal, sehingga jumlah individu yang dapat dihitung dalam plot pengamatan jauh berkurang dari yang seharusnya. Berbeda dengan bulu babi $S$. sphaeroides, bintang ular Ophiocoma scolopendrina yang menjadi penyumbang jumlah individu paling banyak pada habitat batu yang ditutupi alga bukan merupakan jenis yang dapat dikonsumsi, sehingga jumlahnya tidak dipengaruhi oleh aktivitas masyarakat pada waktu tersebut. 


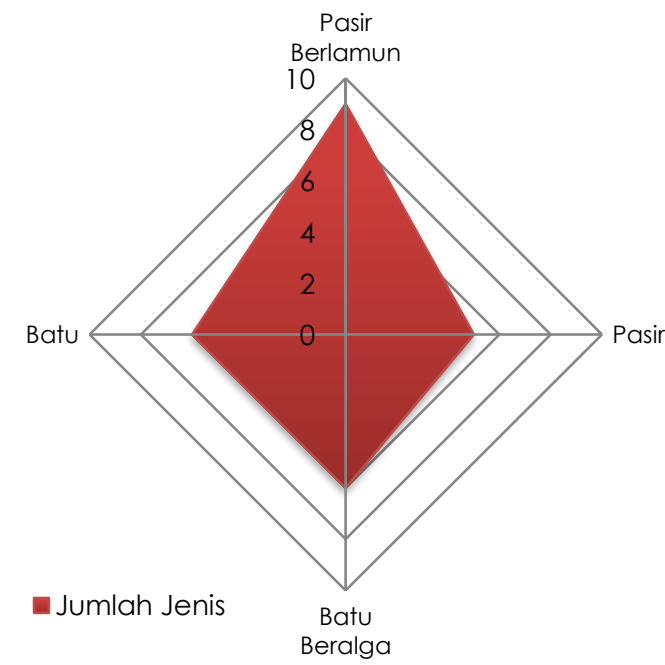

Jumlah jenis Echinodermata

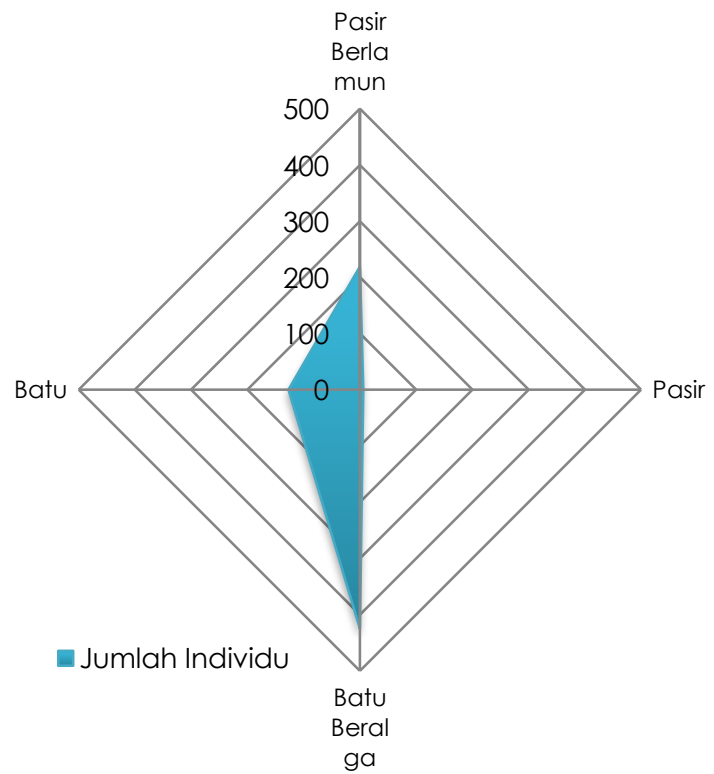

Jumlah individu Echinodermata

Gambar 3. Distribusi Echinodermata pada berbagai tipe habitat di daerah intertidal Pantai Lakeba:

Sargassum merupakan habitat bagi berbagai jenis epifauna seperti Gammaridae Amphipoda, Isopoda, dan Gastropoda (Viejo, 1999). Epifauna adalah organisme yang hidup di permukaan substrat. Keberadaan epifauna yang menjadi makanan bagi $O$. scolopendrina ini diduga merupakan penyebab melimpahnya $O$. scolopendrina.

Berdasarkan hasil analisis keanekaragaman $\left(H^{\prime}\right)$ diketahui bahwa keanekaragaman jenis Echinodermata di daerah intertidal Pantai Lakeba dikategorikan sedang $\left(H^{\prime}=1,42180\right)$ (Tabel 2). Keanekaragaman jenis Echinodermata di pantai ini lebih tinggi dibandingkan beberapa perairan lain yang telah diteliti seperti perairan Wakatobi (Yusron, 2016), Gili Meno, Lombok Utara (Ghafari et al., 2019), Pantai Tawang, Pacitan (Muzaki et al., 2019), perairan Pulau Osi, Seram Barat (Yusron \& Edward, 2019), dan perairan Pulau Lombok (Yusron, 2013). Namun keanekaragaman Echinodermata ini masih lebih rendah dibandingkan nilai keanekaragaman Echinodermata di perairan Suli, Teluk Baguala, Maluku (Uneputty et al., 2017), Pantai Pidakan, Pacitan (Muzaki et al., 2019), perairan Pulau Muna (Yusron, 2003), perairan pantai selatan
Pulau Lombok (Bahri et al., 2021), dan Teluk Weda, Pulau Halmahera (Radjab et al., 2014).

Berdasarkan hasil analisis kemerataan diketahui bahwa kemerataan Echinodermata di Pantai Lakeba tergolong sedang $(E=0,49191)$ (Tabel 2). Namun nilai kemerataan ini di bawah angka 0,5. Nilai kemerataan di bawah 0,5 menunjukkan bahwa komunitas Echinodermata di pantai ini berada dalam kondisi tertekan. Nilai dominansi Echinodermata menunjukkan bahwa tidak ada jenis Echinodermata yang mendominasi $(D=0,36601)$ (Tabel 2) di daerah intertidal Pantai Lakeba.

Keanekaragaman jenis dipengaruhi oleh jumlah jenis yang ditemukan dan jumlah individu masing-masing jenis tersebut. Semakin merata jumlah individu pada masing-masing jenis yang ditemukan, semakin tinggi keanekaragamannya. Namun hasil pengamatan yang dilakukan menunjukkan bahwa Echinodermata yang ditemukan memiliki jumlah individu yang tidak merata. Ada jenis yang ditemukan sangat banyak hingga ratusan individu (O. scolopendrina dan S. sphaeroides) dan ada yang hanya jenis yang hanya ditemukan satu individu (M. planulata, 
Tabel 1. Struktur Komunitas Echinodermata di Daerah Intertidal Pantai Lakeba Nama IImiah

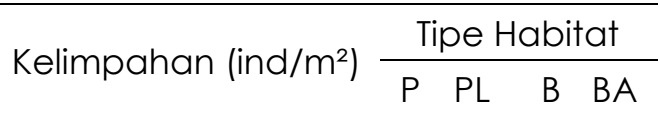

Kelas Echinoidea

(Camarodonta: Temnopleuridae)

Salmacis sphaeroides (Linnaeus, 1758)

Mespilia globulus (Linnaeus, 1758)

0,30333

0,06000

(Camarodonta: Toxopneustidae

Tripneustes gratilla (Linnaeus, 1758)

(Camarodonta: Echinometridae)

Echinometra mathaei (Blainville, 1825)

(Diadematoida: Diadematidae)

Diadema setosum (Leske, 1778)

(Spatangoida: Maretiidae)

Maretia planulata (Lamarck, 1816)

(Spatangoida: Brissidae)

Brissus latecarinatus (Leske, 1778)

(Clypeasteroida: Clypeasteridae)

Arachnoides placenta (Linnaeus, 1758)

Kelas Holothuroidea

(Holothuriida: Holothuriidae)

Holothuria (Halodeima) atra Jaeger, 1833

Holothuria (Metriatyla) scabra Jaeger, 1833

Holothuria (Mertensiothuria) leucospilota (Brandt, 1835)

(Synallactida: Stichopodidae)

Stichopus horrens Selenka, 1867

(Apodida: Synaptidae)

Opheodesoma grisea (Semper, 1867)

Kelas Ophiuroidea

(Ophiacanthida: Ophiocomidae)

Ophiocoma scolopendrina (Lamarck, 1816)

0,71167

Ophiomastix annulosa (Lamarck, 1816)

0,08333

0,00500

0,00167

0,00167

0,00167

0,01667

$+\quad+$

(Amphilepidida: Hemieuryalidae)

Ophioplocus imbricatus (Müller \& Troschel, 1842)

Kelas Asteroidea

(Valvatida: Archasteridae)

Archaster typicus Müller \& Troschel, 1840

Kelas Crinoidea

Ordo Isocrinida

Famili Isocrinidae Gislén, 1924

$0,00500+$

$0,06333+$

$0,01667++$

$+$

$+$

$+$

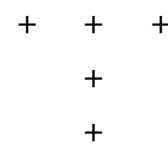

$+$

$0,00667+$ 0,00167 $+$

Keterangan: $\mathrm{P}=$ Pasir; $\mathrm{PL}=$ Pasir yang ditutupi lamun; $\mathrm{B}=\mathrm{Batu} ; \mathrm{BA}=$ Batu yang ditutupi alga 
Tabel 2. Keanekaragaman, kemerataan, dan dominansi Echinodermata di daerah intertidal Pantai Lakeba

\begin{tabular}{ccc}
\hline Variabel & Nilai & Kategori \\
\hline Keanekaragaman $\left(H^{\prime}\right)$ & 1,42180 & Sedang \\
Kemerataan (E) & 0,49191 & Sedang \\
Dominansi (D) & 0,36601 & Tidak ada jenis yang dominan \\
\hline
\end{tabular}

A. placenta, H. scabra, H. leucospilota, S. horrens, dan Isocrinidae). Hal ini mempengaruhi keanekaragaman jenis Echinodermata di Pantai Lakeba.

Menurut Muzaki et al. (2019), ada keterkaitan antara keanekaragaman organisme dengan kemerataan dan dominansinya. Kemerataan menunjukkan sebaran jumlah individu suatu jenis dalam komunitas, sedangkan dominansi menunjukkan ada tidaknya jenis yang memiliki jumlah individu paling dominan dalam komunitas. Apabila kemerataan rendah, maka keanekaragaman juga rendah. Sebaliknya, apabila dominansi tinggi, maka keanekaragaman cenderung rendah karena adanya jenis yang dominan menunjukkan sebaran jumlah individu yang sangat tidak merata atau kemerataannya rendah.

Sejumlah faktor antropogenik diduga menjadi penyebab yang mempengaruhi struktur komunitas Echinodermata di daerah intertidal Pantai Lakeba. Penyebab yang paling menonjol dan dapat diamati langsung sangat pengambilan sampel adalah adanya pengambilan beberapa spesies secara massal seperti S. sphaeroides dan T. gratilla. Kedua jenis bulu babi ini sangat disukai karena rasanya yang enak. Bagian yang dikonsumsi adalah gonad atau sel kelaminnya, yang oleh masyarakat setempat lebih umum disebut sebagai telurnya. Gonad bulu babi ini mengandung protein yang tinggi, sehingga dapat menjadi variasi lauk bagi masyarakat. Tidak hanya untuk dikonsumsi pribadi, bulu babi ini juga dapat dijual, sehingga tidak jarang jenis ini ditemukan dijual di pasar setempat.

Selain bulu babi, teripang juga diduga diambil oleh nelayan setempat untuk diperdagangkan. Beberapa jenis teripang bernilai ekonomis yang ditemukan di pantai ini yaitu $H$. atra, H. scabra, H. leucospilota, dan $S$. horrens. Walaupun jenis-jenis ini hanya ditemukan dalam jumlah sedikit, namun hal ini sudah menunjukkan bahwa Pantai Lakeba dihuni oleh jenis-jenis teripang bernilai ekonomis tinggi. Belum dapat dipastikan dengan jelas mengenai ada tidaknya eksploitasi teripang di daerah ini yang menyebabkan jenis-jenis teripang ini ditemukan dalam jumlah yang sangat sedikit.

Selain faktor di atas, adanya perahu nelayan yang ditemukan tertambat di bagian Timur Laut pantai dan adanya kapal besar yang berlabuh tidak jauh dari pantai ini juga menunjukkan adanya aktivitas manusia di perairan Pantai Lakeba. Pantai Lakeba juga merupakan salah satu destinasi wisata, sehingga di pesisir pantai ini terdapat sejumlah restoran dan vila. Walaupun belum diketahui secara pasti seberapa besar dampak yang ditimbulkan oleh beberapa faktor antropogenik ini, namun hal ini diduga dapat mempengaruhi struktur komunitas organisme intertidal yang hidup di Pantai Lakeba, khususnya Echinodermata.

\section{KESIMPULAN}

Komunitas Echinodermata di daerah intertidal Pantai Lakeba ditemukan pada empat tipe habitat yang berbeda yaitu pasir, pasir yang ditutupi lamun, batu, dan batu yang ditutupi alga. Jenis Echinodermata yang mendiami berbagai tipe habitat ini terdiri atas 18 jenis Echinodermata dari 5 kelas. Keanekaragaman jenis Echinodermata sedang, kemerataan jenis sedang, dan tidak ada jenis yang dominan dalam komunitas. Komunitas Echinodermata yang hidup di daerah intertidal pantai dipengaruhi oleh faktor antropogenik. Perlunya penelitian lanjutan mengenai komunitas organisme 
yang hidup di daerah intertidal, utamanya yang mendapat pengaruh dari aktivitas antropogenik.

\section{UCAPAN TERIMA KASIH}

Penulis mengucapkan terimakasih kepada Lembaga Penelitian dan Pengabdian Masyarakat Universitas Muhammadiyah Buton yang telah mendanai penelitian ini dalam program Riset Unggulan Kajian Keilmuan Bidang Studi (RUKKBIS) Tahun Anggaran 2020 No. Kontrak: B/131/UMB.3.2/PT.01.03/2020.

\section{DAFTAR PUSTAKA}

Azkab, M.H. 1999. Pedoman Inventarisasi Lamun. Oseana, XXIV(1):1-16.

Bahri, S., Patech, L.R., Zulhalifah, Z., Septiani, D. A., \& Siswadi, S. 2021. Distribution and Diversity of Echinoderms in the Coastal Waters of South Beach of Lombok Island. Jurnal Biologi Tropis, 21(1):22. doi: 10.29 303/jbt.v21i1.2320

BPS. 2021. Kota Baubau dalam Angka 2021. BPS Kota Baubau.

Brown, N.P. \& Eddy, S.D. 2015. Echinoderm Aquaculture. Wiley Blackwell.

Clark, A.M. \& Rowe, F.W.E. 1971. Monograph of Shallow-Water Indo-West Pacific Echinoderms. Trustees of the British Museum (Natural History).

Coteur, G., Gosselin, P., Wantier, P., Chambost-Manciet, Y., Danis, B., Pernet, P., Warnau, M. \& Dubois, P. 2003. Echinoderms as Bioindicators, Bioassays, and Impact Assessment Tools of Sediment-Associated Metals and PCBs in the North Sea. Archives of Environmental Contamination and Toxicology, 45(2): 190-202. doi: 10.1007/s00244-003-0199-x

Devaney, D.M. 1970. Studies on Ophiocomid Brittlestars. I. A New Genus (Clarkcoma) of Ophiocominae with a Reevaluation of the Genus Ophiocoma. In Smithsonian Institution Press (Issue 51). doi : 10.5479/ si.00810282.51

Devaney, D.M. 1978. A Review of the Genus Ophiomastix (Ophiuroidea: Ophiocomidae). Micronesica, 14(2):273-359.

Garrison, T., \& Ellis, R. 2016. Oceanography: An Invitation to Marine Science (9th ed.). Cengage Learning.

Ghafari, M.I.A., Hadiprayitno, G., Ilhamdi, M.L., \& Satyawan, N.M. 2019. Struktur Komunitas
Echinodermata di Kawasan Intertidal Gili Meno, Lombok Utara. Al-Kauniyah: Jurnal Biologi, 12(2):181-188. doi : 10.15408/kau niyah.v12i2.10871

Hartati, R., Widianingsih, Trianto, A., Zainuri, M., \& Ambariyanto. 2017. The Abundance of Prospective Natural Food for Sea Cucumber Holothuria atra at Karimunjawa Island Waters, Jepara, Indonesia. Biodiversitas, 18(3):947-953. doi: 10.13057/biodiv/d180311

Hickman, C.P., Keen, S.L., Eisenhour, D.J., Larson, A., \& l'Anson, H. 2017. Integrated Principles of Zoology (Seventeent). McGraw-Hill Education.

Hwang, H., Han, J.H., Lee, S., Ryu, Y.M., Paik, I. H., Min, H.K. \& Paek, W.K. 2015. Invertebrates Fauna in the Intertidal Regions of Yubudo Island, South Korea. Journal of Asia-Pacific Biodiversity, 8(1): 66-71. doi: 10.1016/j.japb.2015.01.007

Jha, B., Reddy, C.R.K., Thakur, M.C., \& Rao, M. U. 2009. Seaweeds of India: The Diversity and Distribution of Seaweeds of the Gujarat Coast (M. A. Borowitzka (ed.)). Springer. doi: 10.1007/978-90-481-2488-6

Klumpp, D.W., Salita-Espinosa J.T., \& Fortes, M. D. 1993. Feeding Ecology and Trophic Role of Sea Urchins in a Tropical Seagrass Community. Aquatic Botany, 45(2-3): 205229. doi: 10.1016/0304-3770(93)90022-O

Krebs, C.J. 1989. Ecological Methodology (New York). Harper \& Row.

Massin, C., Zulfigar, Y., Hwai, A.T.S., \& Boss, S.Z. R. 2002. The Genus Stichopus (Echinodermata: Holothuroidea) from Johore Marine Park (Malaysia) with the Description of Two New Species. Bulletin Del'Institut Royal Des Sciences Naturelles De Belgique, 72:73-99.

Meadows, P.S. \& Campbell, J.I. 1988. An Introduction to Marine Science. In Tertiary Level Biology (2nd Editio). Blackie, Halsted Press. doi: 10.1007/978-94-015-7329-0

Miller, S., \& Harley, J. 2013. Zoology. In Zoology (Tenth Edit, Vol. 10). McGraw Hill Educatin. Muzaki, F.K., Setiawan, E., Insany, G.F.A., Dewi, N.K. \& Subagio, I.B. 2019. Community Structure of Echinoderms in Seagrass Beds of Pacitan Beaches, East Java, Indonesia. Biodiversitas, 20 (7):1787-1793. doi: 10.130 57/biodiv/d200701

Odum, E.P., \& Barett, G.W. 2005. Fundamental of Ecology (5th Edition). Thomson 
Brooks/Cole.

Portocali, P., lliopoulou-Georgudaki, J., Catsiki, V.A. \& Papapetropoulou, M. 1997. The Role of Echinoderms as Bioindicators of Seawater Pollution: A Case Study from Patraicos and Corinthiacos Gulf, N. Peloponnesus, Greece. Toxicological and Environmental Chemistry, 59(1-4): 293303. doi: $10.1080 / 02772249709358443$

Purwati, P. \& Lane, D.J.W. 2004. Asteroidea of the Anambas Expedition 2002. Raffles Bulletin of Zoology, 11 (11):89-102.

Radjab, A.W., Rumahenga, S.A., Soamole, A., Polnaya, D., \& Barends, W. 2014. Keragaman dan Kepadatan Ekinodermata di Perairan Teluk Weda, Maluku Utara. Jurnal Ilmu Dan Teknologi Kelautan Tropis, 6(1):17-30.

Samritin, Agusalim, Iksan, M., Aba, L., Taharu, F. I., Manan, Batlajery, S., \& Tambaru, R. 2019. Structure of Echinoderm Community in Nirwana Beach, Used as Learning Media on the Beach Ecosystem. IOP Conference Series: Earth and Environmental Science, 343(1). doi : 10.1088/1755-1315/343/1/01 2139

Samyn, Y. 2003. Shallow-Water Holothuroidea (Echinodermata) from Kenya and Pemba Island, Tanzania. In Studies in Afrotropical Zoology Vol. 292, Issue January 2003. Royal Museum for Central Africa.

Setiawan, R., Atmowidi, T., Widayati, K.A., \& Purwati, P. 2018. Preferensi Habitat Spesies Ophiuroidea di Zona Intertidal Pantai Pancur Taman Nasional Alas Purwo. Jurnal Kelautan: Indonesian Journal of Marine Science and Technology, 11(2):151-166. doi: 10.21107 /jk.v1 1i2.4741

Suwartimah, K., Wati, D.S., Endrawati, H. \& Hartati, R. 2017. Komposisi Echinodermata Di Rataan Litoral Terumbu Karang Pantai Krakal, Gunung Kidul,Yogyakarta. Buletin Oseanografi Marina, 6(1):53-60. doi: 10.14710/buloma. v6il.15743

Uneputty, P.A., Tuapattinaja, M.A., \&
Pattikawa, J.A. 2017. Density and Diversity of Echinoderms in Seagrass Bed, Baguala Bay, Maluku, Eastern Indonesia. International Journal of Fisheries and Aquatic Studies, 5(2):311-315.

Vandenspiegel, D., Lane, D.J.W., Stampanato, S., \& Jangoux, M. 1998. The Asteroid Fauna (Echinodermata) of Singapore, with a Distribution Table and an Illustrated Identification to the Species. Raffles Bulletin of Zoology, 46(2):431-470.

Viejo, R.M. 1999. Mobile Epifauna Inhabiting the Invasive Sargassum muticum and Two Local Seaweeds in Northern Spain. Aquatic Botany, $64(2): 131-149$. doi: 10.10 16/S0304-3770(99)00011-X

Vindia, W.I., Julyantoro, P.G.S. \& Wulandari, E. 2018. Asosiasi Echinodermata pada Ekosistem Padang Lamun di Pantai Samuh, Nusa Dua, Bali. Journal of Marine and Aquatic Sciences, 5(1):100-108. doi: 10.24843/jmas.2019.v05.i01.p13

Yusron, E. 2003. Fauna Echinodermata di Daerah Terumbu Karang Di Pulau-Pulau Muna, Sulawesi Tenggara. Pusat Penelitian Oseanografi, LIPI.

Yusron, E. 2013. Biodiversitas Fauna Ekhinodermata (Holothuroidea, Echinoidea, Asteroidea dan Ophiuroidea) di Perairan Pulau Lombok, Nusa Tenggara Barat. Zoo Indonesia, 22(1):1-10. doi: 10.52508/zi.v22i 1.315

Yusron, E. 2016. Community Structure Echinoderms (Asteroidea, Ophiuroidea, Echinoidea and Holothuroidea) in the Marine National Park East Sulawesi Wakatobi. Jurnal IImu Dan Teknologi Kelautan Tropis, 8(1):357-366. doi: 10.29244/jitkt.v8i1.13898

Yusron, E. \& Edward. 2019. Diversitas Ekhinodermata (Asteroidea, Echinoidea dan Holothuroidea) di Perairan Pulau Osi, Seram Barat-Maluku Tengah. Jurnal IImu Dan Teknologi Kelautan Tropis, 11 (2):437446. doi: 10.29244/jitkt.v1 1i2.20109 